\title{
SCORCHED EARTH POLICY
}

\author{
Sylvia Townsend Warner
}

(The New Yorker, 18 April 1942)

Colonel Edmund Pomeroy (retired) and his wife, Dollie, lived in the wilds of Huntingdonshire, where the descendants of Cromwell's Ironsides go proudly to chapel and leave the Church of England to strangers, families disgraced by bankruptcy or bastardy, and the gentry, and where the landscape rises and falls in the slow rollers of a clay soil.

It is an elm-tree soil. And now, in the third spring of war, the elms that took so much goodness out of the ground were shedding their blooms, and the Pomeroys' goats were spitting them out and complaining fastidiously.

The Colonel's face, as he stooped seriously above the onion bed, suddenly cracked open in a grin. 'Why, good Lord! Those goats will do it for us,' he said. 'What a fool I was to overlook the goats! Dollie! All we need do about destroying the garden is to shut up the goats in it.'

'Not shoot them?' She was halfway up a ladder, pruning an apple tree. The words, spoken in a piping treble, floated down like some odd bird song.

'Not I!' said the Colonel with decision. 'Four live goats running loose, and one of them that damned Selina of yours, would be as good as a band of guerrillas any day. No, no! It would be short-sighted to shoot the goats. I bet those Russians would never shoot Selina.'

'What about the potatoes, though? We have enough to last all through the summer.'

'Potatoes? Easy. They just go into the pond. What a mercy, I say, that we never got round to draining that pond!' 
'Or we could pour parafin on them'

'Mustn't waste paraffin. We shall want all the paraffin we can spare for the hayrick.'

' $I$ 've sometimes felt rather uneasy about our store of paraffin,' Dollie said. 'It's seemed rather like hoarding. But I'm thankful now.'

'We shall need every drop of it,' said the Colonel. 'I wish to God we'd kept the car. Can't scorch anything with two bicycles.'

From the outset of the war the Pomeroys had set themselves to produce, to conserve, to economize. 'Bound to be a shortage of wood,' the Colonel had said, daubing Solignum on the framework of his blackout screens. 'Nails, too. Pick up those bent ones, my dear, and put 'em in a box, and I'll straighten 'em later.'

'About those damsons,' his wife had said. 'I'm going to dry them. I shall want all the sugar I can save for extra marmalade.'

No shortage found the Pomeroys unforeseeing. When onions vanished, 'First Prize, Bunch of Leeks, Presented by Colonel Pomeroy' enriched every local whist drive held for a good cause. When oranges disappeared, the cookies at the Evacuee Children's Christmas Tea were flavoured with Mrs. Pomeroy's dried-and-pounded orange peel. When wrapping paper was discontinued, string bags, made by Colonel Pomeroy in his spare time from oddments of string collected by Mrs. Pomeroy, were sold for the Red Cross. They raised mushrooms in their air-raid shelter, lettuces among their roses, potatoes on their lawn. Producing, saving, conserving - what else was there, they said, for two septuagenarian fogies living in the wilds to do? Naturally, Mrs. Pomeroy found herself in charge of a salvage dump, where, during hot weather, she put on her gas mask (for there is a use for everything, even gas masks) and sorted old bones. Inevitably, Colonel Pomeroy became an air-raid warden, and a Home Guard, and a billeting officer, and heroically paraded on occasions of local pageantry with an armhand lettered 'B.O.' But these were by-activities. Wartime economy was their daily bread. 
As war and economy went on, the Pomeroys' hoards and contrivances filled the house. But still there was a place for everything - for tin foil, and corks, and empty cotton reels, and rubber bands, and heeltaps of soap, and tobacco pried from cigarette stubs, and sawdust, and shavings, and razor blades, and dandlelion roots (coffee), and cinders, and old felt hats that could be made into bedroom slippers; the Colonel's frame for making camouflage nets fitted quite well into the bathroom, the airing cupboard was excellent for drying mushrooms and raising seedlings in, and when Mrs. Pomeroy had filled every jam pot and pickle jar, she began filling a collection of Grecian urns bequeathed by an aunt. Everything was so neatly arranged that the general effect was merely one of a more extensive neatness; and amid all their economies the Pomeroys contrived to go on improving their pockethandkerchief property, the Colonel making new shelves and cupboards out of packing cases and Mrs. Pomeroy sewing new patch-work coats for the chairs and sofas, and both of them uniting to rebuild the dilapidated summerhouse as a goat shed.

'It seems a pity that we can't use Selina indoors too,' continued the Colonel.

'I've got the inside of the house pretty well planned,' Dollie said. 'Once you've got a bonfire going, I shall bring out the sheets and the blankets. The mattresses are rather a problem, but I shall do what I can with the air-raid hatchet and then upset the sand and water buckets over the remains. As for the pillows I thought I'd shove some of the feathers down the toilet, to block the drains. Boots and shoes can go into that invaluable pond. I thought you'd see to that while I was ripping up the clothes. Then there's all the food. It seemed to me that I might very well begin by emptying some treacle into the salted beans, and the parsnip wine can go into the pickledcabbage tub, along with the soap. Things like flour and tea and oat-meal - they're no trouble. Just skirmish them about on the floor. Then, while you're smashing the canned stuff, I deal with the jam and maybe just frisk through the china cupboard. Do you remember that sideshow there used to be at fairs - a dresserful of cheap crockery and twopence a shy? 
Breaking Up the Home, it was called.'

'The secret is to aim at the shelf,' the Colonel said. 'People aim at the china. You'll see nine out of ten make that mistake. But a good lam at the shelf - that's what brings 'em down.'

'How to scorch the coal cellar - that beats me. This wartime coal -'

'Leave the coal, my dear, and wish 'em joy of it.'

'What will you do about all your lovely tools?

'Pond,' the Colonel said firmly. 'They go in first of all. Except the hammer, for dealing with the windows and doors and so forth. Damn these weeds. Beginning to come up all over the place.'

He went stiffly down on his knees, saying that it needed hoeing, really.

'I'm so sorry,' Dollie said. 'I meant to weed this morning. But the jelly took longer than I meant. Six pots.'

'Hm, that's not bad. Sugar still holding out?'

'Mary Amstice is letting me have three pounds of hers as a swap for tomato ketchup. Jack, I've had an idea! Can't we burst the boiler?'

'Eh?'

'If we let all the water run out and then stoke up the fire and get it nicely roaring just before we leave. That would burst the boiler, wouldn't it? It does at Christmas, in frozen homes. Yes, and that would solve the saucepans, too. We could leave them on the hot plate, empty, to burn their bottoms out.'

'That's a very good idea, Dollie. A damn good idea. And while you're about it, you might remember to burn my flute. I'll be damned if they go breathing down my flute.' He rose. 'What about some tea?'

They walked toward the house, neat as a toy below the elm trees. The kitchen window was open and on the sill stood six pots of jelly. In the afternoon stillness they could hear the fluttering breath of the kettle, just coming to a boil.

The Colonel began to whistle softly. Lightly, Mrs. Pomeroy put her hand on his arm, her small, horny hand, smelling of fruit and of earth. They turned and looked back over the garden. But their scrutiny did not remain there. They 
stared at the empty, rolling landscape, at the calm sky, as though searching for a signal that would release them, after the years of saving and conserving and piecemeal prudence, into the positiveness of destruction.

\section{Copyrighted image removed}

Dust jacket design by Phoebe Llewellyn Smith for the 1977

Chatto \& Windus reprint 